\title{
TABAYYUN AS A CRUCIAL ASPECT IN THE QURANIC CONCEPT OF UMMAH ANALYSIS OF “TABAYYUN" IN SURA AL-HUJURAAT (49:6)
}

\author{
Anggi Azzuhri ${ }^{1}$ \\ ${ }^{1}$ Islamic Studies, Doha, Qatar, Hamid bin Khalifa University, aazzuhri@hbku.edu.qa
}

\begin{abstract}
Khairu Ummah appears in surah 3:110 associated with the society in which Prophet Muhammad lived. This term shows that there is a supreme concept of the highest level of civilization since the society of that period is considered as an excellent civilization. Examining the semantic concept of Tabayyun is a step to reveal the specific aspect to gain the status of the ideal Ummah. This work is deciphering the concept of Tabayyun according to the Qur'an through two main approaches: Semantic analysis and Composition examination. These both methods are conducted by two distinguished contemporary scholars, Toshihiko Izutsu and Hamiduddin Al-Farahi, to find the philosophical meaning of a particular term from the Qur'an. Eventually, it is concluded that the Tabayyun definition is an important high-level social ethics that only true believer can perform it. The absence of Tabayyun leads not only to a wrong decision but to a major conflict in society even the disintegration of it.
\end{abstract}

Keywords: Tabayyun, Semantic Analysis, Khairu Ummmah

Abstrak. Khairu Ummah muncul dalam surah 3: 110 terkait dengan masyarakat di mana Nabi Muhammad tinggal. Istilah ini menunjukkan adanya konsep tertinggi dari peradaban tingkat tertinggi karena masyarakat pada masa itu dianggap sebagai peradaban yang unggul. Menelaah konsep semantik Tabayyun merupakan langkah untuk mengungkap aspek spesifik untuk mendapatkan status umat yang ideal. Karya ini menguraikan konsep 
Tabayyun menurut Al-Qur'an melalui dua pendekatan utama: Analisis Semantik dan Pemeriksaan komposisi. Kedua metode ini dilakukan oleh dua cendekiawan kontemporer terkemuka, Toshihiko Izutsu dan Hamiduddin Al-Farahi, untuk menemukan makna filosofis dari istilah tertentu dari Al-Qur'an. Akhirnya, disimpulkan bahwa definisi Tabayyun adalah etika sosial tingkat tinggi yang penting yang hanya dapat dilakukan oleh mukmin sejati. Absennya Tabayyun tidak hanya mengarah pada keputusan yang salah tetapi juga konflik besar dalam masyarakat bahkan perpecahannya.

Kata Kunci: Tabayyun, Analisis Semantik, Khairu Ummmah

\section{Introduction}

The Ideal Ummah, a translation of the term khairu ummah which appears in surah Ali Imran verse 110, is described as an advanced society in all aspects of life compared to other existing societies in a particular era. (الزحيلي، 1991) Despite the Qur'an has specifically defined the three main concepts of the ideal Ummah within the verse 110: Promotion of Virtue, Prevention of Vice, and Iman in Allah; the semantic field analysis of the phrase ideal ummah, even the word ummah itself, gives such contribution for constructing the concept of Ideal Ummah.

The term "ideal ummah" describes a particular society that has fulfilled the requirements for being distinguished from other societies. This phrase contains two specific words خير khair means ideal or distinction and أمة ummah means society or nation. Nonetheless, there is no proper translation in other languages that represents the true meaning of ummah. Hence, many scholars prefer to keep using the transliteration of that word(ummah) due to its distinction. According to the Qur'an, the term "ideal ummah" refers to the Muslims who live at the time of Prophet Muhammad (PBUH) based on the description of Asbaabun Nuzul from Muqaatil bin Sulaiman that the verse 110 and 111 were revealed for 
the hard talk between Jews and four Sahaba; Ubay bin Ka'ab, Abdullah bin Mas'ud, Mu'ath bin Jabal, and Salim Mawla Abi Huzaifa; Jews were claiming that they are the best ummah ever than others, then the verse revokes their false claim and insists the distinction of Muslim due to three things which have been mentioned previously.

Promotion of Virtue, Prevention of Vice, and Iman in Allah, those three requirements are the major requirements which their meaning is very general and needs more particular definition for each. Building an ideal ummah cannot be conducted if the definition of those three main concepts remains unexplained in detail. In another word, this establishment requires the concrete detailed concepts of ideal ummah which certainly should be derived from the Qur'an.

Iman in Allah is the concept possessing has a deep semantic field, compared to the two others concept. Iman or believe is the term that is shared by many religions, including Jewish, Christianity, and Islam. However, as completely explained by Toshihiko Izutsu, Iman in Islamic view is not the same Iman in other doctrines, neither Jewish, Christianity, Hinduism, Buddhist, or Sabaean. Because Iman in the Qur'an view has several huqul dilali or semantic field that expands the meaning of Iman from just committing to believing as it appears in the lexical Arabic dictionary. Understanding the Qur'an is also necessarily conducted in certain methodologies not freely exegeted thus probably leads to the misunderstanding of the Qur'an. To expand the meaning of Iman to find the concept of Ideal Ummah, the methodology that can be utilized is reviewing the composition of the Qur'an.

Iman and Ummah are frequently found assembling in the Madani surah rather than Makki surah. It is very reasonable because the main topic in Madani surah is mostly about methodology in constructing an unsurpassed society that possesses Iman. Analyzing the entire Madani surah to derive the concept of the ideal ummah is a megaproject that is impossible to be done in a short time. Therefore, determining particular surah even certain verse is a must in this 
study. In this case, we have chosen one of the necessary verses which describe an urgent thing in the ideal ummah. The topic to be discussed in this study is the term Tabayyun from surah 49 (Al-Hujuraat) verse 6:

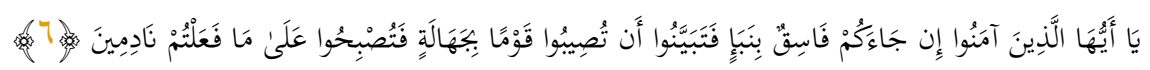

O YOU who have attained to faith! If any iniquitous person comes to you with a [slanderous] tale, use your discernment, lest you hurt people unwittingly and afterwards be filled with remorse for what you have done. $(49: 6)^{1}$

Then, there are several questions concerning the semantic of the term tabayyun. What is the meaning of this word epistemologically? Is this word having the same meaning as investigating and examining? What makes Tabayyun is very necessary in the ideal Ummah and where is its place in the establishment of it? Does it have a disgraceful consequence effect if the ummah leaves Tabayyun? and what benefits gained by performing the Tabayyun in the ummah? These questions are concerning the concept of Tabayyun, however, there is an urgent question before the detail of Tabayyun, why surah Al-Hujuraat is one of two places in which the word Tabayyun is found in command form and what is the role of this surah in constructing Ideal Ummah? It can be answered by explaining the structure of Al-Hujuraat and the distinguished things that are only found in Al-Hujuraat.

\section{Role of Surah Al-Hujuraat in Constructing Ideal Ummah}

The Major Topic in Surah Al-Hujuraat

Surah Al-Hujuraat is the chapter 49th in the Mushafi order and is classified as Madani surah due to its characters and the period of revelation which was after the Prophet's Hijra to Madinah. The Madani surahs have special characters that distinguish them from the Makki surahs, one of them is revealing the laws, obligations, and bounds for individual life and social life. (البغا، 1998) This

\footnotetext{
${ }^{1}$ Translation of Qur'an by Muhammad Asad.
} 
indicates the role of these surahs in building the advanced strong tranquil society. Since Surah Al-Hujuraat is a Medina surah, it is evident in general that this Surah, at least, provides the readers with the Qur'an concepts concerning social life. It has 18 verses, preceding the surah Qaf and a subsequent chapter after Surah Al-Fath.

If we comprehensively read and contemplate the content of the whole surah, several general messages are delivered to the mind. These points can be called the major themes of surah Al-Hujuraat. Generally, this surah describing what every Mu'min or the believers must do and must avoid in a particular condition. The major topics in Surah Al-Hujuraat are:

1. The three verses in the top tier of surah are regarding the ethical issues in interaction with Prophet Muhammad (PBUH). Concisely the first verse warns the believers to not put themselves before Allah and the Prophet. The second verse orders the believers to lower their voice in front of the Prophet. The third verse describes the righteousness of those who act what the previous verse asked.

2. The fourth and the fifth verses warn the believers about forbidding of calling the Prophet from his chamber (Al-Hujuraat, from which the surah name is taken).

3. The next verse concerns the information from the disobedient (fasiq) and the urgency of investigating the Information, so-called Tabayyun.

4. The following two verses are focusing on the Prophet role, Iman, Fasiq, Kufr, sin doers, and reminding the bounties from God.

5. The ninth and the tenth verses explain the reconciliation and brotherhood in faith importance.

6. The next three verses elucidate the honor and dignity of every human being. From the prohibition of taunting others, calling others with unacceptable names, supposition and prejudicing, eavesdropping and spying, and gossiping. This section is closed by the equity of human beings, no differences between humans except with taqwa or righteousness. 
7. The last section of Surah Al-Hujuraat describes the meaning and indicators of Iman itself, such as the claim from an A'rabi or a Bedouin in faith, then the Qur'an revoke that claim as the Iman has stages.

Those topics in Surah Al-Hujuraat indicate the great role of this surah in social life. Some Mufaseer or exegetes name the Surah with "Akhlaq wa Adab" which means "the ethics and the morals" due to its content and messages that mostly regarding the ethical and morals value. ${ }^{2}$

The Composition of Surah Al-Hujuraat

Since this study is also utilizing the methodology nizamul Qur'an (the composition of The Qur'an), it necessarily requires finding the structure of this surah based on some exegesis on the coherences between verses and topics. nizamul Qur'an or the composition of the Qur'an is a view to the coherences and system that build the structure of Qur'an, Nizam Al-Qur'an helps mufasers to expand the new understanding of the Qur'an without breaking the bounds of reason. ${ }^{3}$ The composition scope includes the semantic of terms, the arrangement of surah, the correlation between all surahs. This composition, however, is unable to be known unless by dividing ${ }^{4}$ the Qur'an from the general detail to the smallest details. ${ }^{5}$ Sayyid Hawwa in his work about the principles of exegesis uttered that to find the coherence and the correlation between surah in the Qur'an, the readers (in this case means the mufassir) are required to divide the Qur'an into four parts; majmu'ah or cluster; faqra or paragraph; maqta' or part; qism or segment; respectively. ${ }^{6}$

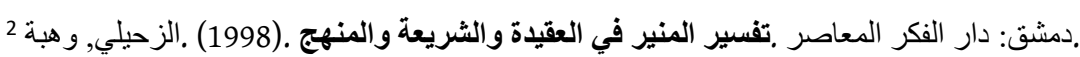

${ }^{3}$ M. Cuypers, The Composition of the Qur'an; Rhetoric Analysis. (London: Bloomsbury Academic, 2015).

${ }^{4}$ In Arabic, this process is called التفكيك tafkeek

${ }^{5}$ M. Cuypers, The Composition of the Qur'an; Rhetoric Analysis. (London: Bloomsbury Academic, 2015).

6 . (2004). القاهرة: دار السلام .الأساس في التفسير.
} 
Regarding the composition of Surah Al-Hujuraat, a contemporary mufassir, Wahba Az-Zuhayli explained the coherence of verses within this surah and the correlation between Surah Al- Hujuraat (49) and Surah Al-Fath (48). In the previous surah, the closing statement in the last verses is:

[But] unto such of them as may [yet] attain to faith and do righteous deeds, God has promised forgiveness and a reward supreme.?

Likewise, the beginning of most verses in Surah Al-Hujuraat is "O you who believe!". There is a clear indication that the Surah Al-Hujuraat is describing the advanced concept of Iman, each verse starts with the call of believers describes what each mu'min is supposed to do. ${ }^{8}$

Therefore, the composition of Surah Al-Hujuraat can be described in the following statement from Wahba Az-Zuhayli: This surah has given every Mu'min how to develop their quality of Iman or how to reach the perfection of faith mainly in the social aspect, from respecting the Prophet Muhammad (PBUH), never stop to investigate (Tabayyun) all information to prevent society schism, strengthening the brotherhood among mu'min, the prohibition of taunting eavesdropping, gossiping, and mistrusting. ${ }^{9}$ Besides, the believers have to respect other human beings because everyone is equal under God's vision except the muttaqin ${ }^{10}$. The closing topic, Bedouin's Iman claim, this surah also indicates that all who claim themselves as the believers, their claims are worthless before fulfilling all the aspects that are mentioned in previous verses.

All the previously mentioned, are the minor concepts for constructing the ideal ummah. Since of the requirements to build ideal ummah is Iman, particularly perfection of Iman, and to reach that perfection, whoever claim their faith, must comply with those concepts.

\footnotetext{
7 According to Muhammad Asad's translation of Qur'an.

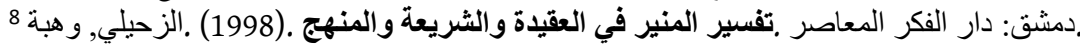

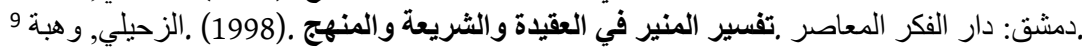

${ }^{10}$ The righteous people, this term itself has a deep meaning which cannot be explained further here.
} 
The Sixth and Seventh Verses

To be more specific in the topic of this study, the sixth and the seventh verse of Surah Al-Hujuraat are strongly related to the topic. The term of Tabayyun appears in the sixth verse and the following verse is explaining the consequence and the danger of the absence of Tabayyun.

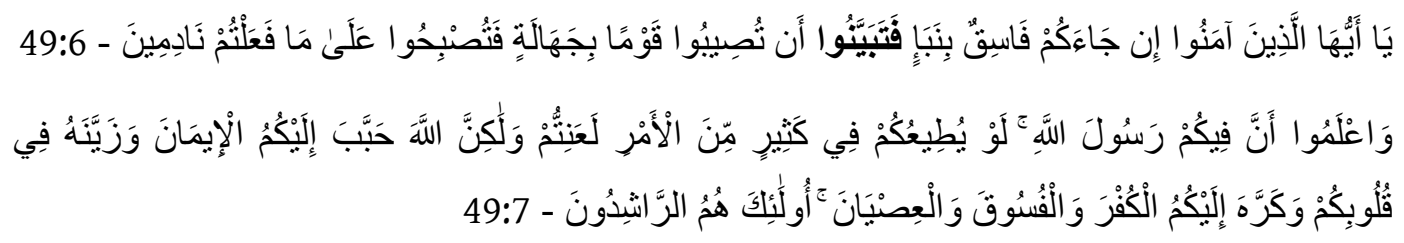

O you who have believed, if there comes to you a disobedient one with information, investigate, lest you harm a people out of ignorance and become, over what you have done, regretful. (6) And know that among you is the Messenger of Allah. If he were to obey you in much of the matter, you would be in difficulty, but Allah has endeared to you the faith and has made it pleasing in your hearts and has made hateful to your disbelief, defiance and disobedience. Those are the [rightly] guided. (7) (Al-Hujuraat-49)

The term Tabayyun in the sixth verse appears in the form of the command (فل الأمر) and is preceded by the ف that indicate a subsequent immediate action. The term Tabayyun in similar meaning can be found in other places in the Qur'an but in a different form of words, such as in the verse in which the detail of the fasting process is explained.

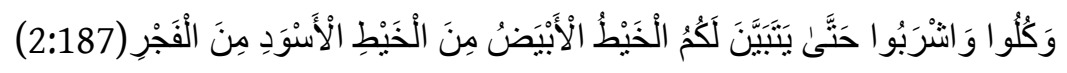

And eat and drink until the white thread of dawn becomes distinct to you from the black thread [of night]. (2:187)

The term "yatabayyana" here refers to a different meaning rather than the "fatabayyanu" in Surah Al-Hujuraat. Hence, it is necessary to study the semantic field of the word to understand the proper meaning of this term. The advanced 
explanation regarding this linguistic meaning is discussed in the following part of the study.

However, before proceeding to the next part of the study in which the term of Tabayyun is discussed, one that should be acquired is the Asbabun Nuzul if it is available. According to Ibn Jarir At-Tabari in his Tafsir, this verse was revealed in the case of Walid bin Uqbah, one of the sahaba who commanded by the Prophet Muhammad (PBUH) to collect the zakat from Bani Mustalaq, a tribe who live in the outskirt of Madinah. There was a previous clash between Walid bin Uqbah and that tribe thus leads to the scariness in Walid bin Uqbah. As the tribe learned that Walid is heading towards them, they prepare for a reception outside the town in which they live. Due to his scariness, Walid mistrusts them that the tribe is coming to kill him, then brings him an immediate return to Madinah with the invalid information. Madinah people are preparing the infantry to counter the tribe based on the Walid's information, which is invalid, then the verse is revealed for validating the news (الطبري، 1994). This Asbabun Nuzul helps this study in finding the proper meaning of Tabayyun.

\section{Analyzing the Structure and Semantic Field}

Tabayyun in Linguistic Definition

Discovering the specific meaning of the term "Tabayyun" requires two aspects of analysis; linguistic meaning which is taken from the dictionaries, and the contextual meaning in the Qur'anic view, which is analyzed from the exegesis, mainly the linguistic exegesis. The former is the main interest of this section of the study, whereas the latter is the result of deep analysis of Tafsir or Exegesis, sematic field, and Nazm or composition. The result is expected to appear at the end of this part. 
The word “تَيَيَّن "Tabayyana" is a derivation of the basic form of an Arabic word بَانَ “Baana" which means "distinct” in verbal form. ${ }^{11}$ The addition of $ت$ ta' in the first syllable and tashdid in the middle syllable refers to advanced level of "to be clear", in this case, Ibnul Manzur in Lisanul Arab, one of the most distinguished Arabic classic dictionary, uttered that the meaning of “tabayyana" and بين "bayyana" are cognate, "to investigate" or "to clarify" or make something clear and valid. ${ }^{12}$ Furthermore, a similar explanation can be found also in three other dictionaries: mu'jam al-waseeth, mu'jam za-id, mu'jam alghaniy.

Tabayyun itself is the gerund (in Arabic known as Masdar) of the word "tabayyana", this term is utilized as the absolute word to describe the action of investigating in Arabic. Nevertheless, there is a word origin from the exact form تبين "tabayyana” but refer to other meaning. That word is تبيان "tibyaan" which implies "who or what explains". ${ }^{13}$ This word appears in the Qur'an once in Surah An-Nahl (49) verse 89 as a genitive of the Qur'an. Despite the difference, both words are supposed to share an important thing in the semantic field study.

To specify the linguistic definition of Tabayyun, here a couple of examples of Arabic sentences: (وقد تبينت أن هذا الكتاب رخيص) I have clarified that this book is cheap. In this sentence the meaning of تنينت is "I have clarified..." or also can be expressed "I have investigated...”. Another example: ( قد تبين الصبح بخط تبين The dawn has been clear by the white line in the horizon”, the word (البيض here implies "It has been clear". From these examples, the general perception of Tabayyun is something that previously was unclear, afterward becomes clear by clarification or investigation.

Analysis of the Sixth Verse

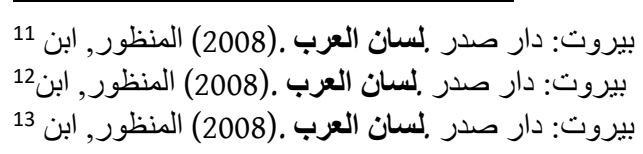


Although "Tabayyun" is found, in several verses, regardless of its form, none of those verses utter this word in command style unless in two verses. The first one is in the surah An-Nisa'(4:94) and another verse is in what has been mentioned, the sixth verse of Al-Hujuraat. Both have a similar linguistic meaning but different context, in surah 4:94 the Qur'an utilizes "fatabayyanu" in the context of the war situation since Qur'an also explains the rules of war. Meanwhile, the same term in surah (49:6) is used in the peace situation context thus leads to differentiating of implication.

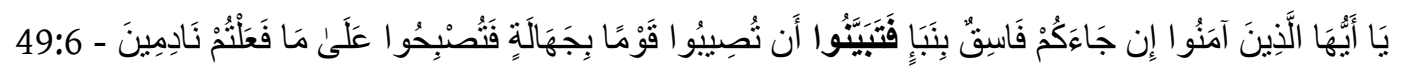
O you who have believed, if there comes to you a disobedient one with information, investigate, lest you harm a people out of ignorance and become, over what you have done, regretful. (6)

To analyze this verse, it is crucial to dismantling this verse into sections first, before proceeding to the whole composition of the verse and the coherences between the next verse and the whole surah. Therefore, the sections that can be divided from this verse are:

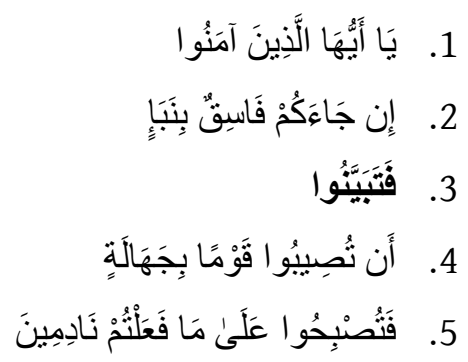

This division is according to Fakhruddin Ar-Razi's exegesis work and Ibn Ashur's exegesis.

Start from the opening of this verse, "O you who have believed". This sort of call determines the address of what this verse contains, in this case, is the mu'min. The determination of address is known in Arabic term تخصيص takhsis or specialization. The term "O you who have believed" is agreed by all scholars as 
to the specialization of the latter content of the verse. ${ }^{14}$ For instance, the verse concerning the fasting command begins with "O you who have believed" thus this verse implies the command only delivers to Mu'min.

In the next section of this verse, the Qur'an gives a conditional clause: "if there comes to you a disobedient one with information". This section is considered as the starting point of the later sections' content. The conditional clause is a piece of information that is brought by a disobedient, which the Qur'an utters as Fasiq. Fasiq is a term for a person who steps out from the true path of Allah. This definition is a combination of literal and contextual definition. The Islamic creed experts also place a definition of Fasiq, this term implies disobedience. ${ }^{15}$ Nonetheless, this verse has a cause of revelation which has been mentioned previously, and using the word disobedience for one of the Sahaba is unwise action. Therefore, some scholars utter that despite the terminological definition of fasiq is disobedient, in this verse the preferred definition is the lowest level of definition, stepping out from the supposed path. ${ }^{16}$

However, the usage of the lowest level of definition reveals that there are some stages of Fasiq who should be investigated every time he brings a piece of information. The lowest level of Fasiq, means the probability of faking is very low, is whoever stepping out from the proper way by doing very minor mistake, such as lying due to afraid. Oppose to this, the highest stage of Fasiq is who commits major sins, and enduringly lie (الرازي, 1981). These stages are revealed in the exegesis of the seventh verse in which the three disliked conditions; infidel, disobey, and sinner. Hence, the current section implies "every information that is brought by Fasiq, in all semantic understanding of it."

The following section is commanding mu'min an immediate action after receiving the information from the fasiq. This is the part of the verse that utter

\footnotetext{
تونس: دار سحنون بتفسير التحرير والتنوير . عاثور, محمد الطاهر (2004).

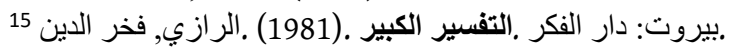

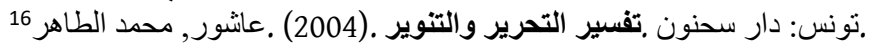


the term "Tabayyun", which implies "to investigate" or "to clarify". Tabayyun in this context has two viewpoints, made by some mufassir. Firstly, it is said that the meaning تبين Tabayyun here is تثبت Tathabbut, translated to English as "to prove" ${ }^{17}$ This viewpoint is built on the difference of Qiraat, Hamza, and Kisai school of Qiraat read this verse as I فتنتبت "fatathabbatu" instead of "fatabayyanu". Secondly, Tabayyun in this verse means "to investigate", and this viewpoint is the majority's view. ${ }^{18}$ However, if these two viewpoints are examined further, no major difference is found between the two definitions of it. All lead to one action, which is "investigating or proving for validity".

The term of Tabayyun is also belonging to the semantic field that can be derived from the previous two-section explanation. First, Tabayyun has a similar meaning with Tathabbut, because of the similarity of process. Probably, the point that differs between both is that Tabayyun or investigation is more general than proofing. In some cases, the investigation does not require a final verdict, its result is open to many possibilities. For instance, investigating the cause of the flat tire. Initially, the investigators compile many data and facts, then examine those matters, and at last, they conduct some possibilities and pointing at the most possible one if they are able. Whereas the proofing, despite goes on the same process, eventually a final decision or verdict is a must, and in most cases, goes deductively.

The second semantic field that can be derived is, Tabayyun is seeking further information, as it appears in the form of Tibyaan which means the explainer. ${ }^{19}$ The result of returning its form onto the basic form reveals the third semantic field of Tabayyun, it can be simplified as "what is clear from something, specifically the information". Furthermore, Tabayyun is strongly connected to iman, information, fasiq, ignorance, knowledge, and brotherhood harmony. This connection is discussed in the last section of this part of the study.

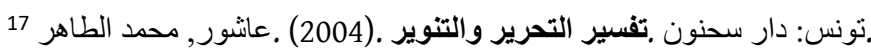

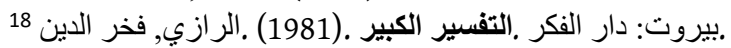

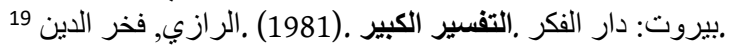


The last two sections of this verse division are explaining the subsequent event if the Tabayyun is left or poorly performed by the Mu'min. In these sections of verse, two words should be the focus on, first الجهالة "jahalah" or ignorance and then نادمين “nadimiin" or regret. Both terms reveal to the reader of Qur'an that the absence of investigation ends on either massive ignorance because the word of ignorance is preceded by "qaum" which implies society, or social regression. ${ }^{20}$ Even, it is possible that both, ignorance and regretful, happen in society as the result of the absence of investigation.

Eventually, some questions emerge about the relation between asbabun nuzul and this verse, does this verse giving a verdict on Walid bin Mughirah as a fasiq thus leads to the cancelation of a paradigm that each Sahaba is free from disobedience? If not, why the Qur'an uses the term fasiq in this verse? Wahba Az-Zuhayli in his tafsir al-munir had given a strong explanation on these questions. First, the term Fasiq here is not implied on Walid bin Mughirah, since he was among trustworthy companions whom Prophet imposed a duty of collecting sadaqa, this imposes certainly required a trust. Therefore, the Fasiq in this verse does not particularly imply Walid bin Mughirah. However, the term is used for general forthcoming cases that would happen after the Walid's case. Second, the term itself is a multi-definition term that can be understood depends on the context as previously explained regarding the stages of Fasiq. ${ }^{21}$

Analyzing the Structure of Surah and The Relation to Tabayyun

After analyzing the content of the sixth verse in which the term Tabayyun exists, the following process is ascending the focus of analysis from the sections (قسم) and the parts (قطعة) to the paragraph and eventually to

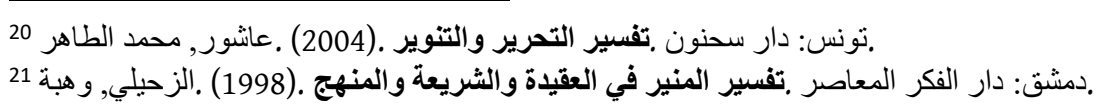


the cluster (مجموعة). This process is conducted to reach a further understanding of the term by utilizing the Nazm Qur'an methodology. ${ }^{22}$ (حوى, 2004).

In the previous part of the study, we have described the main themes of Surah Al-Hujuraat. The sixth verse is containing a distinguished topic that is not mentioned in the other verse, whereas the other topics are discussed at least in two verses. For instance, the topic of brotherhood is the main topic of two verses despite the first initially talks concerning the conflict among the believers. Nevertheless, no doubt that the entire surah Al-Hujuraat plays a big role in giving a deep understanding of Tabayyun.

The sixth verse is strongly connected to the previous verses. According to the explanation from Wahba Az-Zuhayli, the first verse to the sixth verse of surah 49 describe the most necessary ethics and morals which compulsorily come along within ummah, otherwise, the ummah can easily collapse. Those ethics are obedience of God and Prophet, respecting the Prophet, investigating the information, warning the danger of reliance on single-source information, and prohibition of spreading invalid news. ${ }^{23}$ All the previously mentioned values are the main content of the first to the sixth verse of Surah Al-Hujuraat.

Subsequently, the relation between the sixth verse and the following verses is that the seventh verse presents the importance of the Prophet who was the decider of actions at the time. The decider of action is crucially needing valid information before deciding something. Also, regarding the bounty from Allah that the information became clear earlier thus the chaos did not take place. The eighth and ninth verses describe the consequence that probably happens if the investigating is left by society. The consequence is the conflict between believers. However, the Qur'an also has given the solution for the conflict if it goes on by the reconciliation which at the same time, this verse

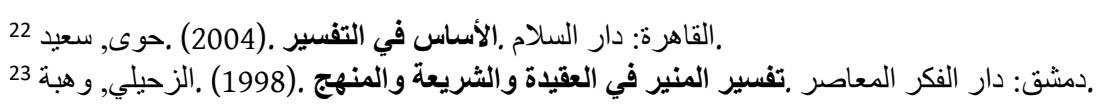


refers to the relation between validating the information and the harmony in brotherhood (عاشور, 2004).

The next clusters of this Surah, from the tenth verse to the thirteenth verse are concerning the must-avoid things to retain the harmony of the ummah, but the effect that could be imposed is less severe than the absence of values that are mentioned at the beginning of surah. For example, eavesdropping badly affects society, however, it is not too massive which can collapse society. Compared to the absence of investigating the information that leads to a major conflict in the ummah.

Of the important point in this surah is the verse in which God revokes the claim from a Bedouin that he has been a believer. Allah says that he has not believed enough, hence Allah asks him to say "I have been Muslim". This case reveals the great role of Iman in ethical values application. As it appears in several verses, the initial word used is "O who you have believed" which indicates that the following content is specialized from the believers (Izutsu, Ethico Religious Concepts in The Qur'an, 2015). If two ideas; the God refusal of Iman claim and the call of Believers; are combined, it produces a conclusion that not everyone can apply the ethical values despite declares himself as a mu'min. Then, each ethical and moral values derived from the surah AlHujuraat is likely difficult to apply except for the true believers, including the investigating the information, so-called Tabayyun.

Toshihiko Izutsu, who had written a phenomenal book concerning the semantic field of Iman, did not explain the Tabayyun as the part of Iman semantic field. However, Izutsu had analyzed the distinguished point between Muslim and Mu'min according to the fourteenth and fifteenth verse of Surah AlHujuraat respectively, and also mentioned the existence of qasit or who deviates as a contrast side of Muslim (Izutsu, Ethico Religious Concepts in The Qur'an, 2015). Izutsu's explanation shows that the stages of man in beliefs: Mu'min or believers, Muslim or Submissive, Qasit or deviant, Fasiq or Disobedient, descending respectively. The term of Kufr is verily opposed to Iman, hence it is 
out of the level since the disbelievers lose their faith. From these stages, it can be concluded that the Fasiq's information is more unreliable than Qasit, Muslim's information more valid than the Qasit. Also, the investigation unlikely left by the Muslim and Qasit, and often ignored by the Fasiq. Only the true Mu'min can consistently apply investigation in every piece of information.

Finally, the Tabayyun definition by analyzing the composition of Surah AlHujuraat is an important high-level social ethics that only true believer can perform it. The absence of Tabayyun leads not only to a wrong decision but to a major conflict in society even the collapse of it.

\section{The Urgency of Tabayyun in Ideal Ummah construction}

Fake News and Its Influence on Society Harmony

Fake news or so-called hoax is fabricated information on a particular event that is resulted from several causes and spread for many purposes. Sometimes, fake news is published intentionally for political concern or social concern. ${ }^{24}$ Regardless of whether it is an intentional or unintentional fabrication and publication of the information, hoaxes potentially harm the life of society. The hoaxes do not directly harm the safety of humans and property but impose an indirect cost to society. ${ }^{25}$

Many facts show the riot and chaos in a particular society caused by either misinformation or fabricated information. Even, some of the war also happen due to the fabricated facts made by the irresponsible group. As an example, in the local election in Jakarta, the capital of Indonesia, which took place in early 2017, the hoax was utilized to offend one candidate namely Anies Baswedan. The opponent of him began spreading invalid information and prejudice that if Anies Baswedan was not elected, there will be a Muslim Revolution, this news is

\footnotetext{
${ }^{24}$ R. Schelsinger, "Fake News in Reality.", (2017).

${ }^{25}$ N. Tishler, "Fake Terrorism: Examining Terrorist Groups' Resort to Hoaxing as a Mode of Attack.", Perspective on Terrorism, (2018): 3-13.
} 
published to remove the political right him and ease the other opponent to win the election. ${ }^{26}$ This information, by the way, was denied by the Anies Baswedan himself, his supporters, and even the election committee. Eventually, he was winning the election and none of the revolutions happened.

This fabricated information then harmed the harmony of Jakarta society even among Muslims. 2017 was marked as the year of Jakarta Muslim dissolution since some Muslims were against Anies Baswedan candidacy. Furthermore, due to the hoax, most Muslims in Jakarta particularly practicing Muslims were persecuted by the secular groups. Therefore, it is evident from the previous example that fabricated information or so-called fake news plays a big role in jeopardizing the harmony of Society. Its absence guarantees the intimacy of Society.

Tabayyun As an Effort to Retain the Intimacy of Ummah

Before entering the Tabayyun importance in constructing Ideal Ummah, there is a need for clearing the relation between Ummah and nation or society. Ummah is a term in Arabic that is usually translated to nation or society, even some translations of Qur'an use the nation in each place in which the term Ummah appears. However, some scholars refuse this translation because either the term Nation or Society does not represent the correct definition of Ummah. The term Ummah beyond the definition of both and more general and sacred (Al-Barghouti, 2008). Regardless, society also a part of Ummah definition hence there is an interdisciplinary relation between Ummah and society. This implies constructing a good society is a part of constructing the Ummah.

Investigation of news is the only medicine for healing one disease in Ummah, namely the fake news. The Tabayyun prevents and minimalizes the further problem that could happen because of fake news. Prevent implies

${ }^{26}$ Matsa, E, “The Impact of Fake News: Society.", (2017). 
canceling the further problem before the event, minimalize means reducing those problems. As we repeated previously if everyone in the Ummah commits Tabayyun whenever news, whether it is valid or not, comes to them, there is no possibility for social chaos thus leads to the easing of constructing the ideal Ummah and created critical Mu'min.

\section{Conclusion}

Ideal Ummah is a term that represents the meaning of خير أمة which appears in Surah Ali-Imran (2:110). Despite the difference between the definition of Ummah and Nation or Society, it can be said that society is a minor part of Ummah, and Ummah beyond the definition of either Nation or Society. Regardless of the definition, this study aims to find the sub-concept for constructing the Ideal Ummah concept by analyzing the Qur'an, particularly in Surah Al-Hujuraat. Hence, this surah has given one of those concepts in building the Ideal Ummah.

Tabayyun or investigating the information has a crucial role in starting up the Ummah. Moreover, the Qur'an claims its importance by placing the term of Tabayyun in a special verse and explaining the consequences of the absence of it. The ideal Ummah itself was the perfect social condition, satisfying the main requirements mentioned in Surah Ali-Imran verses 110. One of them is the Iman, and the Iman is belonging a comprehensive semantic meaning. The semantic meaning can be found in every verse which contains the call of believers, and the Tabayyun verse has it. Hence, Tabayyun is a concept for constructing the ideal Ummah. Besides, Tabayyun importance is also supported by the historical facts that reveal the social chaos triggered by the fabricated news and the absence of investigation.

\section{References}

Al-Barghouti, T. (2008). The Umma and the Dawla: the nation state and the Arab Middle East. London: Pluto Press. 
Cuypers, M. (2015). The Composition of the Qur'an; Rhetoric Analysis. London: Bloomsbury Academic.

Haleem, M. A. (2010). Understanding the Qur'an: Themes and Style. London: Islamic Book Tauris.

Hashmi, T. M. (2010). Exordium to Coherence in The Qur'an; Translation book of Hamiduddin Al-Farahi. Lahore: Al-Mawrid.

Izutsu, T. (2002). The God and Man in the Qur'an. Kuala Lumpur: Islamic Book Trust.

Izutsu, T. (2015). Ethico Religious Concepts in The Qur'an. Montreal: McGillQueen's University Press.

Rahman, F. (2009). The Major Themes of Qur'an. Chicago: University of Chicago Press.

Tishler, N. (2018). Fake Terrorism: Examining Terrorist Groups' Resort to Hoaxing as a Mode of Attack. Perspective on Terrorism, 3-13.

$$
\begin{aligned}
& \text { البغا, مصطفى ديب .(1998) .الواضح في علوم القرآن .دمثق: دار الكلام الطيب. } \\
& \text { الرازي, فخر الدين .(1981) .التفسير الكبير .بيروت: دار الفكر. } \\
& \text { الزحيلي, و هبة .(1998) .تفسير المنير في العقيدة والثريعة والمنهج .دمشق: دار الفكر المعاصر. } \\
& \text { السامر ائي, فاضل .(2016) .التعبير القر آني .دمشق: دار ابن كثير. } \\
& \text { السامر ائي, فاضل . (2016) ـبلاغة الكلمات في التعبير القرآني .دمشق: دار دار ابن كثير. } \\
& \text { الطبري, ابن جرير .(1994) .جامع البيان وتأويل آيات القرآن بيروت: دار الفكر. } \\
& \text { المنظور ر ابن . لسان العرب .بيروت: دار صدر. } \\
& \text { حوى, سعيد .(2004) .الأساس في التفسير .القاهرة: دار السلام. } \\
& \text { دراز محمد عبد الله .(2018) .النبأ العظيم .عمان: مكتبة الأهلية. } \\
& \text { عاثور , محمد الطاهر .(2004) .تفسير التحرير والتنوير .تونس: دار سحنون. }
\end{aligned}
$$

Matsa, E. (2017, June 23). The Impact of Fake News: Society. Retrieved from

Kingsley Napley:

https://www.kingsleynapley.co.uk/insights/blogs/criminal-lawblog/the-impact-of-fake-news-society

Schelsinger, R. (2017, April 14). Fake News in Reality. Retrieved from U.S News: https://www.usnews.com/opinion/thomas-jeffersonstreet/articles/2017-04-14/what-is-fake-news-maybe-not-what-youthink

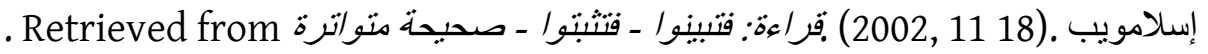

Islamweb: https://www.islamweb.net/ar/fatwa/25028/ 
Jurnal Hunafa: Studia Islamika, Volume 17, Number 2, p. 1-190

E-ISSN: 2355-7710

P-ISSN: $1411-125 \mathrm{X}$ 